\title{
Cannes Celebrates 60
}

\author{
By Ron Holloway
}

Fall 2007 Issue of KINEMA

\section{Feature Report: Cannes Celebrates 60}

By all counts, the $60^{\text {th }}$ Festival de Cannes (16-27 May 2007) will go down as one of the best in its distinguished history as the queen of international film festivals. Délégué Artistique Thierry Frémaux achieved a remarkable balance in the Competition, mixing veteran filmmakers with debutantes and blending, in particular, Asian entries with films by American mainstream and European auteur directors. Further, the Competition was backed by a high-caliber Un Certain Regard section. Indeed, some French critics, reaching for straws, felt that a couple of films in Un Certain Regard surely deserved a slot in the Competition, while a few fiascos in the top drawer section could easily have been downgraded a notch. But this only added to the scuttlebutt in Le Club, the hangout for journalists atop the Palais des Festivals.

The Cannes awards also seemed to fit the anniversary occasion like a glove. One would like to give much of the credit for the right choice of awards to jury president Stephen Frears, save that during a press conference at the opening of the festival some other voices on the international jury seemed just as capable of selecting quality from among the entries. When jury member Orhan Pamuk, the Turkish Nobel Prize winner for literature, was asked about Turkey's future chances to join the European Union, he sidestepped the issue entirely and affirmed instead his respect for film art. Some cinematic insights were also offered by the women on the jury: Portugal's actress-director Maria de Medeiros, Hong Kong actress Maggie Cheung, Canadian actress-director Sarah Polley, and Australian actress Toni Colette. In responding to a question about looking forward to jury duties, Maggie Cheung confirmed that Gilles Jacob had already asked her on two prior occasions to serve on the International Jury. "After turning him down twice - because I was working on a film - I decided it was time to amend the oversight." So the festival was off to a good start before the first film hit the screen.

\section{Golden Palm to Romania}

For the first time in festival history, the Palme d'Or was awarded to an entry from Romania: Cristian Mungiu's 4 luni, 3 saptamini si 2 zile (4 Months, 3 Weeks and 2 Days). Programmed at the outset of festival, it was one of the front runners for Palme consideration from beginning to end and was awarded in addition the International Critics (FIPRESCI) Prize. For that matter, what made Cannes 2007 particularly memorable was the breakthrough by Eastern European directors across the board in all the festival sections. The so-called "new waves" from Romania, Russia, and Hungary were duly celebrated in the press, although some were not really new at all - just being tagged so by some popeyed trendsetting French critics.

Not an easy film to swallow, 4 Months, 3 Weeks and 2 Days is also not easy to forget either. This emotionally searing tale of a university student's illegal abortion in a seedy hotel during the last days of the Ceauscescu dictatorship features rivetting performances by Laura Vasiliu as Gabita, the pregnant girl, and Anamaria Marinca as Otilia, the good-hearted classmate friend pulled into the mess. Shot mostly with a hand-held camera against a bleak wintery background of blues and greys, 4 Months, 3 Weeks and 2 Days explores in numbing words and images a desensitized society in a backwater university town, where everything of human value is tested, impeded, or discarded in the course of a frightful night of uncertainty. Even the friendship between the girls is derailed once Otilia realizes that Gabita has been feeding her half-truths all along that unexpectedly lead to dead ends.

\section{Wong Kar Wai's Blueberry Nights}

Cannes opened with Wong Kar Wai's My Blueberry Nights (Hong Kong-USA), the Hong Kong director's first film shot in the United States. Ever since he was awarded Best Director for Happy Together (a Hong Kong production shot in Buenos Aires) at the 1997 Cannes festival, Wong Kar Wai has been a favored figure at Cannes. Wong returned in 2000 with the critically acclaimed In the Mood for Love, starring Maggie Cheung and Tony Leung (awarded Best Actor). Then, in 2004, his 2046 scared the daylights out of Cannes staffers by arriving just in the nick of time for screen projection in the Competition. However, instead of Cannes 
being angry with the procrastinating filmmaker, the opposite occurred. In 2006, Wong was asked to serve as president of the International Jury. And, this year, his My Blueberry Nights opened the 60th anniversary festival. To my knowledge, few auteurs have been treated with such unquestioning fealty by the Cannes hierarchy.

View Happy Together and In the Mood for Love as the forerunners of a rambling trilogy about love lost and the pain of missed chances, then My Blueberry Nights comes across as a weak rehashing of Wong's primary theme set in bars and restaurants illuminated by neon lights. This time, the director himself seems lost. Despite a cast of name personalities, led by singer Norah Jones in her first acting role, My Blueberry Nights unravels when the scene shifts from Manhattan to Memphis, afterwards to Las Vegas and the wide open spaces, and finally back to New York again. Whether intentional or not, citations from films that had previously made history at Cannes add to the puzzle. Ry Cooder's guitar strains recalls Wim Wenders's Paris, Texas (Golden Palm, 1984), and Norah Jones and Natalie Portman on the open road evokes Ridley Scott's Thelma and Louise (closing night presentation, Cannes 1991). "We're watching the wrong Kar Wai," remarked a critic friend, and I couldn't agree more. Why some foreign directors can't resist the American road movie genre, without knowing how to wed it to their own artistic aesthetic, is beyond comprehension.

\section{Fatih Akin's Edge of Heaven}

Citations from previous Cannes hits have become fashionable of late. Take Turkish-German director Fatih Akin at his word in an interview, then his Auf der anderen Seite (The Edge of Heaven), awarded Best Screenplay by the International Jury and the Ecumenical Prize, was inspired by Guillermo Arriaga's screenplay for Alejandro Gonzalez Iñárritu's Babel (Mexico-USA-France), awarded Best Director at the 2006 Cannes festival. Once again, overlapping stories chart the destinies of six searching individuals, three Germans and three Turks, who don't quite know where they belong although fated to live in two different cultures. A pair of tragic deaths force painful decisions. And although Fassbinder actress Hannah Schygulla makes a respectable cameo appearance as a distraught mother, it's veteran Turkish actor and stage director Tuncel Kurtiz who steals the show as a sympathetic retiree who accidentally kills a prostitute he has fallen in love with.

Like Wong Kar Wai, Fatih Akin has evolved into a Cannes regular. According to an inside source at the Cannes festival, the Turkish-German director narrowly missed an invitation to the Côte d'Azur in 2004 with Gegen die Wand (Head On) - it was entered instead at the Berlinale, where it won the Golden Bear. Subsequently, he was invited to serve on the International Jury at the 2005 Cannes festival, where he also presented his documentary Crossing the Bridge - The Sounds of Istanbul in an out-of-competition slot. There, as jury member, Fatih Akin made the acquaintance of writer Guillermo Arriaga, awarded Best Screenplay for Tommy Lee Jones's The Three Burials of Melquiades Estrada (USA), a multi-layered tale of overlapping destinies set along the Texas border to Mexico. Akin's The Edge of Heaven - the German title reads On the Other Side - doesn't stray far from the same general Arriaga theme of miscommunication among cultures that constantly rub shoulders with each other without comprehending much more than that.

\section{Alexander Sokurov's No-Show}

Although Alexander Sokurov himself has never been awarded a major prize at Cannes, his Alexandra (Russia) marked the fifth occasion that the St. Petersburg auteur has competed at Cannes - a record that puts him on an equal footing with Russian icon director Andrei Tarkovsky. The string began with Molokh (Moloch, 1999) on Hitler, followed by Telets (Taurus, 2001) on Lenin, the one-shot tour of the Hermitage in Russkiy kovcheg (Russian Ark, 2002), and the spiritually poetic and militarily oriented Otets I syn (Father and Son, 2003). Although all were critically acclaimed, only Moloch was singled out for Palm honours: to Sokurov's reported consternation, Yuri Arabov and Marina Koreneva were awarded Best Screenplay. Had the impulsive Russian director not reported ill a day before the scheduled press screening (he doesn't particularly like to fly), Alexandra might have set his Cannes record straight, for the film ranks among Sokurov's best and deserved some kind of personal Cannes recognition.

Alexandra stars Galina Vishnevskaya, the wife of the late celebrated cellist and Russian dissident Mstislav Rostropovich. Well known in her own right as a legendary opera singer, Vishnevskaya is best remembered as Katerina Izmailova in the Russian opera Lady Macbeth of Mtsensk, Dimitry Shostakovich's masterpiece banned under Stalin. Just prior to shooting Alexandra, Alexander Sokurov had made a documentary titled 
Elegiya zhizni - Rostropovich, Vishnevskaya (Elegy of Life - Rostropovich, Vishnevskaya (2006), in which he eulogized both Rostropovich and Vishnevskaya and confirmed his admiration for the Russian opera singer since his childhood. The story of a worried grandmother who pays a visit to Chechnya to visit her grandson, an army officer on the war front, Alexandra required the presence of Galina Vishnevskaya in nearly every sequence. Her self-effacing courtesy to Russian military personnel, although she doesn't approve of the war, is matched by her gentle attention to local Muslim women at an open market, whom she invites to visit her back home. That moment alone highlights the absurdity of the war games surrounding her visit.

\section{Andrei Zvyagintsev's Banishment}

Andrei Zvyagintsev's Izgnanie (The Banishment, Russia) takes up where his Vozvrashcheniye (The Return, 2003), the Golden Lion winner at Venice, had previously left off. Both films star a charismatic actor, Konstantin Lavronenko - awarded Best Actor at Cannes - as father and husband in a spiritual crisis that cannot be resolved by love or forgiveness. To the confusion of many at the press screening, Zvyagintsev dispenses with a narrative line to interpret the protagonist's "banishment" through Old Testament biblical metaphors as the conscience-tortured husband and father of two wrestles with good-and-evil in the depths of his soul - doomed, of course, to lose everything in the end. For when his pregnant wife informs him that the child she's expecting is not his, he suspects his brother and demands an abortion. This hard-heartedness on his part leads to a mishandled abortion and death, the twist coming when the wife tells him she had not told him the whole truth after all. Rather, she just wanted to test the sincerity of his love.

Filmed in Belgium (the dismal rainy scenes) and in Moldova (the bucolic summer scenery), The Banishment relies heavily on images to tell the story. The scenes with lush landscapes marked by rolling hills and abandoned ruins confirm the extraordinary visual mastery of cinematographer Mikhail Krichman, who also collaborated with Andrei Zvyagintsev on The Return. These shots contrast sharply with the dark, depressing images of the city at the opening of the film. Further, the choice of Swedish actress Maria Bonnevie to play the quiet, submissive wife contrasts sharply with Konstantin Lavronenko's agonizing husband with a short fuse.

\section{Béla Tarr's Man from London}

Béla Tarr's The Man from London (Hungary-Germany-France), based on a Georges Simenon novel, may have snuck into the Competition through a convenient French coproduction window. Still the Hungarian director is hardly an unknown name at Cannes. His Werckmeister Harmonies, invited to the Directors Fortnight section at the 2000 festival, was well received by the critics. Widely recognized as one of Europe's leading avant-garde filmmakers, Béla Tarr hit his stride when he collaborated with writer László Krasznahorkai on a five-hour screen adaptation of the latter's Damnation (1987), followed by their seven-and-a-half-hour Sátántangó (1994) and then the two-and-a-half-hour Werckmeister Harmonies. Viewed altogether, these 15 collective hours come across as an apocalyptic allegory on the downfall of socialism in the communist era.

It took a reported seven years before Béla Tarr could find the backing to make The Man from London. Scripted again with László Krasznahorkai, and filmed in his patented bleak black-and-white tones (cinematographer Fred Kelemen), this is the exacting slow-motion story about a night railway-station attendant who witnesses a killing on a pier just after a ferry has docked. By happenstance, the attendant finds himself in possession of a great deal of money found on the person of the murdered man. At the press screening, as The Man from London unwound over a stretch of two hours plus, the audience grew itchy, and many left midway through the crime caper. Some cineaste admirers of Béla Tarr felt that he had compromised himself, although the Cannes invitation might just open up international avenues of further funding. Besides, there wasn't much more the Hungarian auteur could say about the downfall of Stalinism.

\section{Ulrich Seidl's Import Export}

Ulrich Seidl, the enfant terrible of Austrian cinema, has dampened his caustic criticism of a morally decaying, prone-to-violence bourgeois society (Dog Days, 2001) by turning his attention in Import Export (AustriaFrance) to the challenges facing CentEast members of the European Union. And he hits the nail right on the head: the new European Union states have to deal with the spread of drugs, gambling, prostitution, gang beatings, you name it. In the "import" portion of the film a low-paid qualified nurse and single mother leaves the Ukraine for Vienna simply because she needs the money to support her family back home. Along the way she is subjected to assorted humiliations by uncaring employers. In the "export" segment an unemployed 
Viennese security guard, deep in debt, accepts a job delivering second-hand slot machines to Slovakia and the Ukraine. Together with his lamebrain step-father, they sink whatever they earn in sex and alcohol.

Despite the rough edges in Import Export - for, as usual in Seidl's films, some sex scenes are over-exaggerated for effect - the director's sympathy is clearly on the side of the exploited nurse working under degrading conditions in Vienna. And the performance of Ekateryna Rak as Olga touches the heart, particularly when she steals time at a hospital for the ill and aged to sing a lullaby on the phone to her infant child back home. The theme of Import Export? Despair personified. And that's what makes it so hard to overlook or forget this film.

\section{Lee Chang-dong's Secret Sunshine}

Of the two South Korean films programmed in the Competition at Cannes, Lee Chang-dong's Milyang (Secret Sunshine) was the standout. Jeon Do-yeon, in the role of a widowed mother whose only son is kidnapped by a local nut and killed, was deservedly awarded Best Actress by the International Jury. Unravelling at a slow pace of two and a half hours, Secret Sunshine offers a rounded portrait of life in a provincial town amid the struggles of a still young woman to find her footing in the birthplace of her deceased husband, all along subjected to religious ploys and well-meaning but generally useless neighbourly advice. The story is typical of Lee Chang-dong's oeuvre as a writer, screenwriter, and film director, who came to cinema late from a writing career as a socially engaged novelist: The Booty (1983), Burning Papers (1987), and There's a Lot of Shit in Nokcheon (1992). His screenplays for Park Kwang-su - Gesom e kado shipta (To the Starry Island, 1993), Areumdaun chongnyun jeon tae-il (A Single Spark, 1995) - helped considerably to establish the Korean New Wave movement.

Although as a writer-director with only four films to his credit, each of Lee Chang-dong's features is nevertheless a finely crafted statement on contemporary social problems. In Chorok mulgogi (Green Fish, 1996), the story of a young man recently discharged from obligatory military service, Lee underscores how the real world is at odds with the young man's idealistic principles, so much so that by necessity he is dragged into the criminal underworld. In Bakha satang (Peppermint Candy, 2000), invited to the Directors Fortnight at Cannes and the Competition at Karlovy Vary, a young man's suicide before a train at a riverside picnic is told in reverse to explain the reason why he had decided to end his life at this time and place. And in Lee's Oasis (2002), invited to compete at Venice, a young man guilty of manslaughter leaves prison to care for a woman with cerebral palsy, the daughter of the victim of his own hit-and-run accident. In turn, his actions are questioned by a cold and indifferent society.

\section{Kim Ki-duk's Breath}

With 14 films to his credit in eleven years, South Korea's Kim Ki-duk, a director with a social conscience and a style to match, is often compared to another quick-on-the-draw cult director: Germany's Rainer Werner Fassbinder. And like Fassbinder, Kim tends to repeat himself in depicting the struggles of outsiders to find a place in society at whatever cost. Most of his later films echo the themes of his initial back-to-back features: Ag-o (Crocodile, 1996), the story of a homeless lad living under a bridge who saves a girl from drowning only to make her his sex object; and Yasaeng dongmul bohoguyeog (Wild Animals, 1996), the tale of two young men in Paris, one a former soldier from North Korea and the other a street painter from South Korea (Kim himself was an art student in Paris and street painter), whose struggle for survival leads them into the criminal underworld.

Kim Ki-duk's interrelated themes of love and distrust, sex and prostitution, violence and expiation have prompted multiple festival invitations. His Paran daemun (Birdcage Inn, 1998), about a girl who became a prostitute after having been raped by her father, was invited to the Panorama at the 1999 Berlinale. It was followed by invitations to compete at the Berlinale with Nabbeun namja (Bad Guy, 2001), about a girl dragged into prostitution at the hands of a smalltime gangster, and Samaria (Samaritan Girl, 2004), about schoolgirl-prostitution, the latter awarded a Silver Bear for Best Director. In each of these films the theme of crime and innocence is reworked.

Kim's festival record is impressive. He competed at Venice with Seom (The Isle, 1999), Suchwiin bulmyeong (Address Unknown, 2001), and Bin-jip (3-Iron, 2004); at Moscow with Shilje sanghwang (Real Fiction, 2000); at Locarno with Bom yeoreum gaeul gyeoul geurigo bom (Spring, Summer, Fall, Winter ... and Spring, 2003); at Karlovy Vary with Hae anseon (Coast Guard, 2002); at Mar del Plata with Hwal (The Bow, 2005); and 
at Chicago with Shi gan (Time, 2006). Given this lineup, one wonders why it took him so long to receive an invitation to compete at Cannes. Now that it's happened, his melodrama Soom (Breath) offers nothing new. A condemned criminal, who has repeatedly attempted suicide, is visited by a lonely wife, who counters her husband's infidelity by showering her affections on the prisoner. That her colour-splattered, fantasy-filled visits do pierce the criminal's hard crust is beside the point, for they serve more to release her own pent-up emotions and help resolve the marital crisis. Kim Ki-duk doesn't bother to dig deeper than that.

\section{Naomi Kawase's Mourning Forest}

Japanese woman director Naomi Kawase owes much of her international acclaim to three appearances at Cannes. It began when her low-budget film Moe no Suzaku (The God Suzaku, aka Suzaku, 1997), invited to the Directors Fortnight, was awarded the prestigious Caméra d'Or for Best Debut Feature. The story of poor people living in an isolated village, it presupposes the presence of the god Suzaku in the wind and the mountains, a tradition that animates both story and the film. She followed this with Sharasojyu (Shara, aka Shara - Light and Shadow, 2003), the story of a twin boy who mysterious disappears on a traditional feast day and how the family copes with the loss until the mystery is partially solved many years later. Invited to compete at Cannes, Shara features the director herself as the grieving mother.

Grief is also the primary theme in Naomi Kawase's Mogari no mori (The Mourning Forest), a JapaneseFrench coproduction. A woman who is haunted by the loss of her child cares for a senile old man in a retirement home. The pair come to understand each other's grief better during the old man's birthday outing to the countryside. After the woman's car breaks down along the way, they trudge aimlessly through the forest at the insistence of the old man. Finally, after two days of arduous wandering, during which they once engage in a child-like hide-and-seek game, they reach what passes for a grave-site in the forest. There, we discover that this is the 33rd year after the death of the old man's wife. Thus, according to a Japanese Buddhist tradition, he lays flowers on her grave to commemorate a long lost love - and her final departure, for now her spirit will never return again to this earthly world. A magical film of dreams and longing, The Mourning Forest was awarded the runner-up Grand Prix by the International Jury.

\section{Carlos Reygadas's Silent Light}

Mexican auteur Carlos Reygadas also began his Cannes career in the Directors Fortnight. And like Naomi Kawase, Reygadas's Japón (Japan, Mexico-Spain, 2002) was singled out for Caméra d'Or recognition, receiving the runner-up Special Mention. Inspired by the cinema of Andrei Tarkovsky, Japan chronicles the arduous journey of a gaunt old man, apparently a painter, to a remote Mexican village to commit suicide. Once there, he meets an old woman in a shack (named Ascen, or Ascension), requests sex with her, and gradually is reawakened to life again when he helps the old lady resist her conniving son. Reygadas followed this with Batalla en el cielo (Battle in Heaven, Mexico-Belgium-France-Germany, 2005), a much discussed and disputed entry in the Cannes competition. Set in Mexico City during Holy Week and filmed mostly with nonprofessionals, Battle in Heaven is the story of the peculiar sexual relationship between a middle-aged chauffeur to a general and the general's attractive young daughter, who herself works as a prostitute on the side for no evident reason. The film shifts into high gear when it's revealed that the chauffeur and his wife have kidnapped a relative's child for ransom, whose unexpected death then upsets all their plans and leads to a bloody tragedy in the end.

Carlos Reygadas's Stellet Licht (Silent Light, Mexico-France-Netherlands) confirmed his credentials as an original cinematic talent. Unwinding slowly over a two-and-a-half-hour stretch, Silent Light opens with a stunning shot of dawn breaking through a starry night over a peaceful summer rural backdrop that is crowned with the twitching of birds and the lowing of cows. The setting is a Mennonite community in the northern province of Chihuahua, where "Plautdietsch" (Rheinland Dutch-German from the Middle Ages) is spoken amid a smattering of Spanish. A story of adultery - in which the father of a family has apparently already confessed his sin to his wife, yet cannot deny the joy of his forbidden passion - the twist comes when the beloved wife dies and the illicit relationship is broken off at the wish of the other woman. In many respects Silent Light draws its spiritual power from the same source as Danish master Carl Theodor Dreyer's Day of Wrath (1943) and Ordet (1955). In short, as the title hints, the film's theme is redemption. Silent Light was awarded a share of the Prix du Jury (Special Jury Prize) by the International Jury.

\section{Gus Van Sant's Paranoid Park}


Gus Van Sant's Paranoid Park (USA-France) echoes in theme and style his Palme d'Or winner Elephant (2003), a free-flowing fictional account of the Columbine High School massacre. This time, however, Paranoid Park avoids conventional storytelling. Although he has adapted the story from a novel by Blake Nelson and cast the film via MySpace, Gus Van Sant has opted for a stream-of-consciousness aesthetic in order to effectively take the pulse of a frightened 16-year-old skate-boarder from a broken home who has accidentally killed a security guard and doesn't know how to handle the burden of not telling anyone. The lad's catastrophic world leaves little room for emotional release, which in essence is the whole film. Christopher Doyle's cinematography, counterbalanced by Rain Kathy Li's Super-8 skateboarding footage, guarantees at least an arthouse audience, while in a retrospective sense Paranoid Park is the coda to Gus Van Sant's thematic trilogy about alienated youth: Gerry (2002), Elephant (2003), and Last Days (2005). Paranoid Park was awarded the Special 60th Anniversary Prize by the International Jury,

\section{Emir Kusturica's Promise Me This}

Winner of two Palme d'Or awards at Cannes - for Otac na sluzbenom putu (When Father Was Away on Business, Yugoslavia, 1985) and Underground (Yugoslavia, 1995), Emir Kusturica's Zavet (Promise Me This, Serbia-Montenegro-France) is a throwback to the director's first feature, Sjecas li se Dolly Bell? (Do You Remember Dolly Bell?, Yugoslavia, 1981). The story of a country lad sent by his grandfather to the village market to sell a cow and bring back a wife, Promise Me This stars Ljiljana Blagojevi - the original "Dolly Bell" - as a school teacher in this amusing low-budget fable. At the press conference, Nemanja Kusturica (to cite his newly christened Russian-Orthodox name) went out on a limb to say: "All my cinematic life I have been making one movie, Do You Remember Dolly Bell? It's like my first movie is still not finished." Viewed from this perspective, Promise Me This (the film's preferred title at Cannes) is light Serbian village entertainment, chock full of ribald characters (floozies, gangsters, con-men) and shot in a make-believe village erected in Kusturica's own filmmaking image.

\section{American Hits and Misses}

In general, the American entries disappointed. European critics, particularly the French, don't get very excited about films that fail to premiere at Cannes anyway. So what, if David Fincher's Zodiac is an engaging thriller about a never-caught serial killer in San Francisco. OK, so the mafia hitman genre is alive and well in James Gray's We Own the Night. And who cares, if Quentin Tarantino's Death Proof is a raucous salute to John Hughes and Grindhouse movies. Indeed, one has the feeling that Tarantino was invited to bolster the attendance list of past Palme d'Or winners (Pulp Fiction, 1994).

But the critics did get excited about Joel and Ethan Coen's No Country for Old Men, a cross between black comedy and political satire (if Bush-whacking is intended). Starring Tommy Lee Jones as a worn-out sheriff, with Josh Brolin as a luckless cowboy and Vietnam vet who suddenly finds himself in possession of a load of heroin and $\$ 2$ million in greenbacks, the cat-and-mouse story begins when Brolin decides to keep the cash although he knows he'll be tracked by the drug traffickers. Based on Cormac McCarthy's Pulitzer Prize winning novel that's set in 1980, the film chronicles the end of an era on the Tex-Mex border and the dawn of a new age of drugs and violence. This is one of those instances in which the viewer may have to read the book first in order to follow the plot. Personally, I found the specious violence in the film rather tiring as this border tale meandered off in unexpected twists and turns, although Javier Bardem as the psychopath killer can send shivers up your back each time he stalks his next victim. Once again, the cinematography of Roger Deakins, who lensed all of the Coen Brothers's films, can take your breath away.

\section{French Cinema of Sorts}

The best American entry in the Competition? A French one: Le scaphandre et le papillon (The Diving Bell and the Butterfly), directed by Julian Schnabel. The moving story of the editor of the French magazine Elle, who had suffered a massive brain stroke, the afflicted man dictates his passion for life and living from his "diving bell" by blinking his eye lid to release the "butterfly" dreams of his imagination.

The best Asian film in the Competition? Also a French one: Persepolis, a feature-length animation film co-directed by Marjane Satrapi and Vincent Paronnaud. Reportedly condemned by the Iranian government before the film even hit the screen, Persepolis draws upon Iranian writer and graphic-artist Marjane Satrapi's four-volume cycle of stories about an eight-year-old girl (Satrapi herself) growing up in Tehran in 1978, when the Shah was overthrown and the Islamic Revolution emerged to suppress freedom of expression and 
movement. Persepolis was awarded a share of the Prix de Jury (Special Jury Prize) by the International Jury.

As for the official French entries, Christophe Honoré's musical comedy, Les chansons d'amour (Songs of Love), in which lyrics replace dialogue to interpret the thoughts and emotions of three lovers in Paris, came across as a pale tip-of-the-hat to Jacques Demy's splendid Les parapluies de Cherbourg (The Umbrellas of Cherbourg, 1964), the Grand Prix of the 17th Cannes International Film Festival. Also, Raphael Nadjari's Tehilim (Psalms, France-Israel), the story of an Israeli father's mysterious disappearance, compounded by his teenaged son's inability to come to terms with the loss, appears to have been invited to compete at Cannes due to its French coproduction link. Although a slight tale, Psalms does depict the discomfiting gap between orthodox belief and modern family life in present-day Jerusalem. Had the film been slotted in the Un Certain Regard section, it might have fared better.

Catherine Breillat, whose unabashed Sex Is Comedy opened the 2002 Directors Fortnight, returned to Cannes in the Competition with Une vieille maîtresse (An Old Mistress), an adaptation of Jules Barbey d'Aurevilly's scandalous 1865 novel. The story of a handsome young dandy who, after his marriage, pledges to stay away from his long-time mistress benefits from its acerbic dialogue. Not surprising at all, for Catherine Breillat is an adroit novelist with a sure hand for handling her material, in addition to being an accomplished filmmaker whose sensual tales had paved the way for others to follow (Bruno Dumont, Patrice Chereau). What is surprising, however, is that she could celebrate at Cannes a comeback after suffering three years ago a cerebral haemorrhage that threatened to incapacitate her permanently. The upshot? An Old Mistress is arguably her best film.

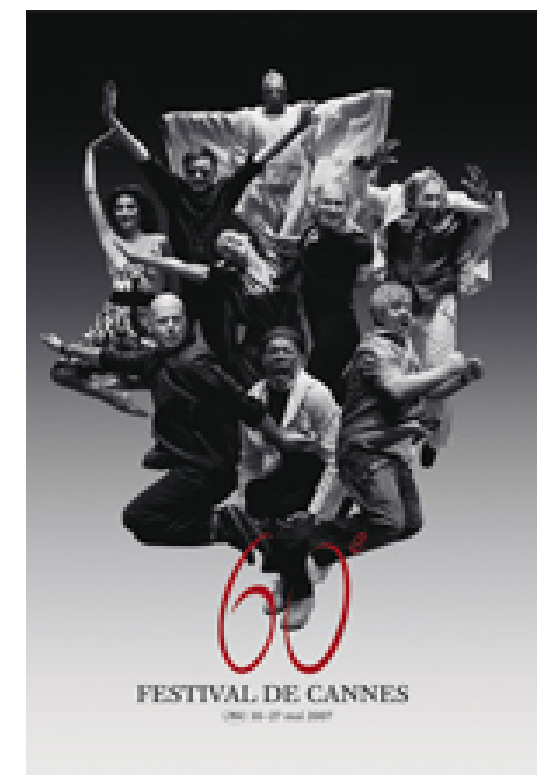

Figure 1: Cannes 2007 official poster

\section{CANNES SIDEBARS}

\section{Out of Competition}

\section{Michael Winterbottom's Mighty Heart}

American cinema received a boost from a film by a British director in an Out-of-Competition slot that arguably belonged in the Competition: Michael Winterbottom's A Mighty Heart. A docu-drama about the kidnapping and murder of Wall Street journalist Danny Pearl in Pakistan, it draws its strength from his pregnant wife Mariane's account of her month-long search for her husband and the vigil she kept until his death was confirmed in a frightful video of the killing. Played convincingly by a pregnant Angelina Jolie, who 
assumes an appropriate accent to interpret the role (Mariane Pearl, an Afro-Cuban with a Dutch passport, was raised in Paris), A Mighty Heart effectively used Cannes as a springboard for later Oscar consideration. During the press conference a journalist stood up in the crowd to apologize personally to Mariane Pearl she present on the podium with Jolie and Winterbottom - for having once asked her an undignified question: whether she had viewed the video-recorded murder of her husband.

\section{Michael Moore's Sicko}

Michael Moore's Sicko - an open-ended, convincingly detailed, tightly edited, and often hilarious attack on American health insurance companies - received a boost from George Bush's White House when objections were raised about a Cuban visit in search of better health care. But Moore contends that Cuba isn't the only country offering better medical service than the United States - others are Canada, France and Great Britain. Sicko argues that the American system of private health insurance is nothing short of a disaster and that a state-run system is much preferred. His arguments are illustrated with statistics, anecdotes, and some frightening stories about Americans with faulty insurance (millions have no insurance at all), who were either denied medical care or forced to sacrifice their entire savings to pay for it.

\section{Denys Arcand's Age of Ignorance}

Programmed at the closing night gala, Denys Arcand's striking L'age des ténèbres (The Age of Ignorance, aka Days of Darkness, Canada-France) comes across as a coda to the Canadian director's previous Cannes hits: Le déclin de l'empire américain (The Decline of the American Empire, 1986) and Les invasions barbares (Invasion of the Barbarians, 2003). Taken as a whole, Arcand's rather extraordinary trilogy is packed with caustic insight, satirical comment, and good ribald fun about the pitfalls of modern-day American society. Indeed, looking back, The Decline of the American Empire, programmed in the Directors Fortnight at Cannes, has proven prophetic and remains a harsh critique of the American "Way of Life." Sixteen years later, Arcand returned to Cannes in the Competition with Invasion of the Barbarians, later awarded an Oscar for Best Foreign Language Film. Hinting that the social and cultural seams in North America had truly split asunder, he predicts an eventual civilization crash. In The Age of Ignorance, Denys Arcand picks up where he left off, the setting this time the fictional Civil Rights Department buried somewhere in Quebec bureaucracy. Billed as a comedy, Arcand's anti-hero is a tame civil servant who clandestinely smokes on the job, can't communicate with his wife and teenaged daughters, and has a sick mother in the hospital. Like a frustrated Walter Mitty, his only outlet is daydreams - where at least he is surrounded by a bevy of beautiful babes.

\section{$60^{\text {th }}$ Anniversary Homages}

\section{Volker Schlöndorff's Ulzhan}

Programmed in the special "60th Anniversary Homages" section to pay honour to previously awarded Palme d'Or directors, Volker Schlöndorff's Ulzhan (Germany-France-Kazakhstan), co-scripted by Claude Carrière, chronicles the stumbling path taken by a French dropout (Philippe Torreton) as he tramps his way across the breadth of Kazakhstan for no reason at all. Rescued at regular intervals by a sympathetic Kazakh miss on horseback, Ulzhan (Ayanat Ksenbai), his journey to nowhere in this picturesque travelogue takes on some spiritual depth when he encounters Shakumi, an itinerant wordsmith. Played with flair by David Bennett best known on the screen as Oskar Matzerath in Schlöndorff's Tin Drum, 1979 Palme d'Or winner - Shakumi makes a living in a fading occupation alien to modern-day civilization. He sells words.

\section{Ermanno Olmi's Hundred Nails}

Similarly, in Ermanno Olmi's Centochiodi ( A Hundred Nails, Italy), the story of another dropout, the film is best interpreted through its religious overtones. After a young university professor (Israeli actor Raz Degan) nails a hundred books to the floor of a research library, he feigns suicide, abandons his BMW convertible, and seeks a new identity in a village on the Po River. There he finds refuge in the ruins of a peasant's house and is welcomed by the villagers as a modern-day messiah. All goes well in his spiritual journey until he makes the fatal mistake of using his credit card - and is hauled back by the police into the mundane secular world to answer for the books he had ravaged. Stunningly photographed by Fabio Olmi (Ermanno's son), particularly scenes depicting the peaceful flow of the Po River, A Hundred Nails may well be Ermanno Olmi's last humanist feature film. The director, at 75, has announced his retirement from filmmaking.

\section{Special Screenings}




\section{Ken Burns and Lynn Novick's The War}

A seven-part series due to air in the United States this coming September, Ken Burns and Lynn Novick's compilation documentary The War strikes a human chord by relating the historical facts to interviews with front-line enlisted men - soldiers, navy men, marines. Each comes from a quintessential American town: Sacramento, California; Mobile, Alabama; Waterbury, Connecticut; and Luverne, Minnesota. Of the seven films in the fourteen-and-a-half-hour running series, I viewed the documentary depicting the last fighting days of the war in Europe and the Pacific. To the filmmakers' credit, they do not pull any punches about the horrendous mistakes made by American leadership in the battles for Hürtgen Forest in Germany and Peleliu Island in the Pacific. In both cases, the needless sacrifice of American life reached into the thousands for so-called "victories" that were in fact useless military engagements, for they hardly accomplished what their leaders had proposed as both strategically necessary and relatively easy to achieve. One wonders whether some military historians will now feel prodded to change their estimates of certain war victories upon hearing what the key eyewitnesses - soldiers, sailors, marines - have to say about the leadership failures of their commanders.

\section{Andrei Nekrasov's Litvinenko Case}

The impromptu Special Screening of Andrei Nekrasov's documentary Rebellion: The Litvinenko Case (UK) underscores how important Cannes has become as a world platform for breaking news events. Just before the festival closed, this hard-hitting documentary on the murder last November of Russian ex-spy Alexander Litvinenko - author of the book "Blowing Up Russia: Terror from Within" - was fitted into an already overcrowded festival program. Based partially on interviews with former KGB agents, the film chronicles the former spy's death in a London hospital from polonium-210 radiation poisoning. At the time when Litvinenko was struck down by lethal radiation poisoning, he had been investigating the death of Russian journalist Anna Politkovskaya.

\section{Un Certain Regard}

\section{Li Yang's Blind Mountain}

Too bad Li Yang's Mang Shan (Blind Mountain, China) had not found its way to the Competition. The story of a young university student kidnapped by human traffickers, who is then sold as a "wife" to villagers in the mountains, the film reportedly had to survive several cuts before release. Still, despite censorship problems, Blind Mountain features a powerful performance by Lu Huang as the sex slave who never gives up the struggle to assert and seek her freedom. Li Yang is the same Chinese director who was awarded a Silver Bear at the Berlinale for his Mang Jing (Blind Shaft, 2003), the grisly story of coal miners plotting "accidental" deaths, then posing as the relatives of the dead men to collect their meagre compensations.

\section{Barbet Schroeder's Terror's Advocate}

Barbet Schroeder's L'avocat de la terreur (The Terror's Advocate, France) deserves a long life on the festival circuit. The story of Jacques Vergès, the lawyer whose stellar success record as a defence attorney began with the Algerian War and carried all the way up to the Klaus Barbie trial that unearthed French collaboration under the German Occupation, The Terror's Advocate draws its power from some fascinating interviews with Jacques Vergès and people who know him intimately. Whether you like the man or not, you cannot help but be impressed by his legal methods of defending people who openly espouse the principles of terror.

\section{Eran Kolirin's Band's Visit}

Awarded a FIPRESCI (International Critics) Prize, Eran Kolirin's Bikur hatizmoret ( The Band's Visit, Israel) is an amusing deadpan comedy that gets better as the tale unwinds in its absurd setting. To start with, an Egyptian Police Band from Alexandria has been invited to play at the opening of a new Israeli cultural centre! But upon arriving at the airport, no one is there to welcome the band. Without bothering to call the Egyptian Embassy for help, the band leader decides to put the musicians on a bus to seek accommodation on their own. Next, they end up isolated in a remote town, with no hotel in sight and no transport out of the place until morning. A friendly kiosk owner offers a solution: why not stay with local families? The idea works, simply because these quaint members of the police band have a knack for cultural communication at its simplest level.

Robert Thalheim's Along Came Tourists

Robert Thalheim's Am Ende kommen Touristen (And Along Came Tourists, Germany) also works its magic 
at the simplest level of communication. A young man who has chosen civil duties over military service arrives in Poland to work at Auschwitz, where he meets a stubborn old survivor. The crusty gentleman, who takes pride in repairing suitcases for the Auschwitz Museum, couldn't care less about the young man's offer to be of assistance. Gradually, however, with the help of Polish neighbours, the German lad learns to fit into the daily routines at the camp. Shot at Auschwitz and its environs, with finely sketched performances by Alexander Fehling as the young German and Ryszard Ronczewski as the old Pole, And Along Came Tourists received a standing ovation at its Cannes premiere.

\section{Hou Hsiao Hsien's Flight of the Red Balloon}

Of course, Hou Hsiao Hsien's Le voyage du ballon rouge (The Flight of the Red Balloon, France-Taiwan) is an unabashed salute to Albert Lamorisse's classic Le ballon rouge (The Red Balloon), the 34-minute Grand Prix winner at the 1956 Cannes film festival - apparently the reason why it was chosen to open the Un Certain Regard section at this year's $60^{\text {th }}$ anniversary festival. Hou Hsiao Hsien's first French film, The Flight of the Red Balloon stars Juliette Binoche as a creative puppeteer who writes and voice-acts her own shows at a children's puppet theater. She's also the mother of a seven-year-old lad (Simon Iteanu), who's in regular conversation with a big red balloon hovering over the streets of Paris, and a harried mother, whose flagrantly neglectful husband phones from time to time from Canada to say he plans to stay longer in Montreal. Add to this ensemble a Taiwanese film student (Song Fang), who speaks fluent French and cares for the boy during the day while touring Paris with a video camera in hand, plus a troublesome downstairs tenant (Hippolyte Girardot), who refuses to pay the rent, and you have a delightful mix of characters to entertain over the two-hour stretch. Finally, there's a throwback to Hou's own The Puppetmaster (Taiwan, 1993) when Binoche pays a visit to an elderly Chinese puppeteer master to recharge her own creative batteries.

\section{Cristian Nemescu's California Dreamin'}

Awarded the Un Certain Regard Prize by a separate international jury, Cristian Nemescu's black comedy California Dreamin' (Nesfarsit) / California Dreamin' (Endless), Romania) theoretically should not have qualified for award consideration at all, for the 27-year-old Romanian director had died in a car accident shortly after completing the shooting on his first feature film - thus the word "endless" added onto the title. But at the award ceremony the section's jury president, French filmmaker Pascale Ferran, confessed that the theme alone of California Dreamin' made it a standout. Based on a true incident that had occurred in June of 1999 during the Kosovo War, a NATO train transporting radar equipment and guarded by American soldiers was stopped at a Romanian village by the railroad station master, who also happened to be the local gangster in cahoots with a corrupt village mayor. Since the Americans were transporting the equipment without official papers (having received only verbal permission from the Romanian government), and since corruption is endemic to Romanian rural life, the incident quickly escalates into a fireball of cultural and political misunderstanding. As for the title, it refers to lyrics in a Mamas and Papas hit rendered by the village damsel on the make with an American soldier.

\section{Roy Andersson's You, the Living}

The companion piece to his previous statement on the vagaries of human life in Sanger fran andra vannigen (Songs from the Second Floor), awarded the Jury Prize at the 2002 Cannes film festival, Swedish director Roy Andersson's Du levande (You, the Living, Sweden-Germany-France-Denmark-Norway) picks up where he left off to comment on the meaningless of life itself. Set against a shabby urban backdrop of cubicle flats, airless offices, dismal bars, and gloomy restaurants, You the Living doesn't stray much beyond Andersson's usual static pessimistic commentary on the miserable state of human existence. This time, however, he peoples his film with a punk guitarist, an Arab barber, a Dixie jazz band, a lady who warbles off-key, an old man with his dog, and a couple other quaint characters to pepper the proceedings with some amusing gags.

\section{Harmony Korine's Mister Lonely}

Harmony Korine's Mister Lonely (UK-France-Ireland-USA), peopled with look-alikes, takes its cue from a Michael Jackson impersonator (Diego Luna) living in Paris who is down on his luck. When he meets a Marilyn Monroe look-alike (Samantha Morton), she invites him to a Scottish castle to meet her lover, a Charlie Chaplin impersonator (Davis Lavant) and other impersonators, who in turn encourage him to put on a show. Along the way Harmony Korine splices in another bizarre tale set in the jungles of Panama. Here, German director Werner Herzog plays a spaced-out priest in the act of encouraging nuns to test their faith by jumping out of aeroplanes without parachutes. To some extent, these episodes draw on the American 
director's own autobiographical experiences. A light film packed with fun and eccentricities, Mister Lonely takes its title from a Bobby Vinton song.

\section{Kadri Kousaar's Magnus}

The first Estonian feature film ever invited to the official program at Cannes, Kadri Kousaar's Magnus (Estonia-UK) introduces a woman director whose debut feature has yet to clear Estonian censors and thus may be available in this version only on the festival circuit. The story of a youth who believes his days are numbered due to a fatal lung disease, he's also convinced that he has power over life and death - so he favours an amoral existence. But as Magnus grows older, he finds that such life-affirming ploys as sex and drugs aren't the answer after all. Then, when his hedonistic, self-indulgent father enters the picture, he finds himself sinking deeper into addiction. Taken as a black comedy, Magnus scores as an amusing father-son caper on outlandish sexual mores, although the laughs initially generated by the old roué on his pornographic binge wear thin over the long run.

\section{Valeria Bruni-Tedeschi's Actresses}

A familiar face in Italian and French cinema with over 60 screen performances to her credit, Valeria BruniTedeschi delved deep into her stage-and-screen profession to direct her second feature: Actrices, aka Le rêve de la nuit d'avant (Actresses, aka Dream of the Night Before, France). Actresses explores the neurotic world of a stage actress (Bruni-Tedeschi herself) as she approaches 40 and still hasn't resolved the conflict between her professional life and personal desire for happiness. Informed that her time is running out to have a child, she begins her inner quest for a husband while rehearsing the role of Natalya Petrovna in Turgenev's play $A$ Month in the Country. Her uncertainty not only affects the stage production, but leads her to converse with her deceased father for possible guidance. Actresses - previously titled The Dream of the Night Before - was awarded a Special Jury Prize in the Un Certain Regard competition.

\section{Semaine Internationale de la Critique}

\section{Etgar Keret and Shira Geffen's Jellyfish}

Awarded the Caméra d'Or prize for Best Debut Feature, Etgar Keret and Shira Geffen's Meduzot (Jellyfish, Israel-France) introduces a pair of accomplished writing talents collaborating for the first time on a film production. The setting is Tel Aviv, where the jellyfish is a part of beach life - used in this instance, however, as a metaphorical ploy to sketch the lives of people who can't control their own destinies. One is a young waitress working for a catering firm, who lives in an apartment with a leaking roof and befriends a sad little girl, who in turn reminds her of her own past. Another is a bride, who breaks her leg at the party on her wedding day and has to cancel the honeymoon trip to the Caribbean. A third is a Filipino woman serving at the wedding reception, whose mind is on phoning her young son back home. The interlocking fates of these and other individuals offer insights into the human condition in today's Israel.

\section{Directors Fortnight}

\section{Anton Corbijn's Control}

Programmed to open the Directors Fortnight, Anton Corbijn's Control (UK-Australia-Japan) sketches the life and times of the legendary Ian Curtis, the lead singer and song writer of Joy Division, an Australian post-punk rock band that took the Manchester music scene by storm in the 1970s. Based on a book of memories penned by his wife, Deborah Curtis's "Touching from the Distance," and lensed in black-andwhite by Dutch photographer-filmmaker Anton Corbijn, the biopic effectively captures the mood and spirit of the heady 1970s, beginning with Ian Curtis as a teenager in 1973 and ending with his suicide in 1980 at the age of 23. Newcomer Sam Riley plays Ian Curtis as a complex personality, wavering between a shy, gentle lad and a selfish, ambitious rocker. The familiar Joy Division songs are performed by actors-musicians without resorting to original recordings. As for the title, it's taken from the Joy Division's "She's Lost Control," with reference to out-of-control circumstances leading to Ian Curtis's suicide.

\section{Jan Bonny's Counterparts}

Jan Bonny's written-and-directed debut feature Gegenüber (Counterparts, Germany) commands attention due to its cast of acting talent on screen. Matthias Brandt, the son of German Nobel Peace Prize winner Willy Brandt, plays the tormented policeman-father, who on the outside maintains the facade of a happy family to friends and neighbours, while at home he's locked in a bitter tug-of-war with his wife. The tantrums of the 
schizophrenic wife, played by Austrian actress Victoria Trauttmansdorff, are explosive and mind-bobbling. Meanwhile, two grown children, a brother-sister pair, are left numb on the sidelines wondering what will come next and how to handle the self-pity of their mother at the more crucial moments. Counterparts doesn't resolve the dilemma of a couple locked in a love-and-hate relationship, other than showing the dead end it will eventually lead to.

\section{Cannes Classics}

\section{Andrzej Wajda's Canal}

The centre piece of Andrzej Wajda's famous War Trilogy - Pokolenie (Generation, 1955), Kanal (Canal, 1957), Popiól i diament (Ashes and Diamonds, 1958) - Canal crowned the 30-year-old Polish director with instant fame when the film was awarded the runner-up Special Jury Prize at the 1957 Cannes festival. For its special screening in the Cannes Classics section, as part of the "Homage to Andrzej Wajda," the film was digitally restored. With the director present, Cannes also paid honour to his Czowiek z zelaza (Man of Iron), awarded the Palme d'Or at the 1981 Cannes festival. The story of the Polish Solidarity movement, Man of Iran was the sequel to his temporarily banned Czowiek z marmuru (Man of Marble, 1977). As for the abiding power of the War Trilogy, Generation broke new ground by probing a tragic love among young Poles during the war years. It was followed by Canal, in which the tragic hero is depicted as a romantic figure against the backdrop of the 1944 Warsaw Uprising. Finally, the stylistic high point of the trilogy was reached in the persona of Zbigniew Cybulski, again a tragic hero entangled in the coils of a new political system after the war has ended.

\section{Digitally Restored Highlights}

Another highlight in the Cannes Classics section was "Laurence Olivier Films William Shakespeare," featuring digitally restored prints of Henry V (1944), Hamlet (1948), and Richard III (1955). Also, the "Centenary of John Wayne" was celebrated with John Farrow's Hondo (1953) and Howard Hawks's Rio Bravo (1959). As well, "Documentaries on Filmmaking" deserve further festival exposure: Mimi Freedman and Leslie Greif's Brando (USA-France-Spain-UK, 2007), Anne-Marie Faux and Jean-Pierre Devillers's Maurice Pialat, L'amour existe (France, 2007), and Todd McCarthy's Man of Cinema: Pierre Rissient (USA, 2007).

\section{References}

\section{AWARDS Official Competition}

Palme d'Or, Best Film

4 luni, 3 saptamini si 2 zile (4 Months, 3 Weeks and 2 Days, Romania), dir Cristian Mungiu

\section{Grand Prix}

Mogari no mori (The Mourning Forest, Japan-France), dir Naomi Kawase

Prix du Jury / Special Jury Prize (ex aequo)

Stellet Licht (Silent Light, Mexico-France-Netherlands), dir Carlos Reygadas

Persepolis (France), dir Marjane Satrapi, Vincent Paronnaud

\section{Best Director}

Julian Schnabel, Le Scaphandre et le papillon (The Diving Bell and the Butterfly, France)

\section{Best Actor}

Konstantin Lavronenko, Izgnanie (The Banishment, Russia), dir Andrei Zvyagintsev

\section{Best Actress}

Jeon Do-yeon, Secret Sunshine (South Korea), dir Lee Chang-dong

\section{Best Screenplay}

Fatih Akin, Auf der anderen Seite (The Edge of Heaven, Germany-Turkey)

\section{Special 60th Anniversary Prize}

Gus Van Sant, Paranoid Park (USA) 


\section{Career Award}

Jane Fonda

Un Certain Regard Prize

California Dreamin' (Nesfarsit) - California Dreamin' (Endless, Romania), dir Cristian Nemescu

Special Jury Prize

Actrices, aka Le rêve de la nuit d'avant (Actresses, aka Dream of the Night Before, France), dir Valeria Bruni-Tedeschi

Prix Coup de Cour

Bikur hatizmoret (The Band's Visit, Israel), dir Eran Kolirin

Palme d'Or, Best Short Film

Ver llover (Watching It Rain, Mexico), dir Elisa Miller

Honourable Mentions

Ah Ma (Grandma, Singapore), dir Anthony Chen

Run (New Zealand), dir Mark Albiston

Caméra d'Or, Best First Film

Meduzot (Jellyfish, Israel-France), dir Etgar Keret, Shira Geffen - Critics Week

Honourable Mention

Control (UK-Australia), dir Anton Corbijn - Directors Fortnight

Directors Fortnight

Prix Regards Jeunes / Young Eyes Prize

Control (UK-Australia), dir Anton Corbijn

Label Europa Cinéma Prize (Best European Film)

Control (UK-Australia), dir Anton Corbijn

CICAE Prix Art et Essai

Garage (Ireland), dir Lenny Abrahamson

Honourable Mentions

Control (UK-Australia), dir Anton Corbijn

Gegenüber (Counterparts, Germany), dir Jan Bonny

FIPRESCI (International Film Critics) Awards

Official Competition

4 luni, 3 saptamini si 2 zile (4 Months, 3 Weeks, and 2 Days, Romania), dir Cristian Mungiu

Un Certain Regard

Bikur hatizmoret (The Band's Visit, Israel), dir Eran Kolirin

Critics Week and Directors Fortnight

Elle s'appelle Sabine (Her Name Is Sabine, France), dir Sandrine Bonnaire - Directors Fortnight

International Critics Week Grand Prize

$X X Y$ (Argentina), dir Lucia Puenzo

SACD - French Society of Dramatic Authors and Composers

Meduzot (Jellyfish, Israel-France), dir Etgar Keret, Shira Geffen

SACD Prize for Best Short Film in French

Même pas mort (France), dir Claudine Natkin

Canal + Grand Prize for the Best Short Film

Madame Tutli-Putli (Canada), dir Chris Lavis, Maciek Sczerbowski 


\section{Ecumenical Jury Prize}

Auf der anderen Seite (The Edge of Heaven, Germany-Turkey), Fatih Akin

\section{Youth Prize}

Bikur hatizmoret (The Band's Visit, Israel), dir Eran Kolirin

French National Education Administration Prize

4 luni, 3 saptamini si 2 zile (4 Months, 3 Weeks, and 2 Days, Romania), dir Cristian Mungiu

Prix France-Culture for Career Achievement

Rithy Panh "for the intensity of his work and his commitment to the presentation of Cambodia's cinematographic memory"

\section{La Cinéfondation Awards}

First Prize

Ahora Todos Parecen Contentos (Now Everybody Seems to Be Happy, Argentina), dir Gonzalo Tobal

Second Prize

Ru Dao (Way Out, China), dir Chen Tao

Third Prize (ex aequo)

A Reunion (South Korea), dir Hong Sung-Hoon

Minus (Serbia), dir Pavle Vuckovi

\section{Author Information}

Ron HOLLOWAY (1933-2009) was an American critic, film historian, filmmaker and correspondent who adopted Europe as his home in the early fifties and spent much of his life in Berlin. He was an expert on the study of German cinema and against all odds produced, with his wife Dorothea, the journal German Film, keeping us up-to-date with the work of directors, producers and writers and the showing of German films around the world.

In 2007, Ron Holloway and his wife were awarded the Berlinale Camera Award. Ron also received the Bundesverdienstkreuz (German Cross of Merit), Polish Rings, Cannes Gold Medaille, the American Cinema Foundation Award, the Diploma for Support of Russian Cinema and an honorary award from the German Film Critics' Association.

Ron was also a valued contributor to Kinema for the past fifteen years. 